\title{
Nursing care to people admitted in emergency for attempted suicide
}

\author{
Cuidado de enfermagem às pessoas atendidas na emergência por tentativa de suicídio \\ Cuidado de enfermería a las personas atendidas en la emergencia por intento de suicidio
}

\section{Mayara Cristine Fontão', Jeferson Rodrigues', Monica Motta Lino', Murielk Motta Lino', Silvana Silveira Kempfer'}

' Universidade Federal de Santa Catarina. Florianópolis, Santa Catarina, Brazil.

\section{How to cite this article:}

Fontão MC, Rodrigues J, Lino MM, Lino MM, Kempfer SS. Nursing care to people admitted in emergency for attempted suicide. Rev Bras Enferm [Internet]. 2018;71(Suppl 5):2199-205. [Thematic Issue: Mental health] DOI: http://dx.doi.org/10.1590/0034-7167-2017-0219

Submission: 04-05-2017

Approval: 09-13-2017

\begin{abstract}
Objective: to analyze the nursing care to people admitted in emergency for attempted suicide in the perception of the nursing staff. Method: descriptive and exploratory study, of qualitative approach, developed from semi-structured interviews with eight nurses and eight nursing technicians of the emergency service of a University Hospital in south Brazil. Data analysis was performed through content analysis. Results: three categories emerged: nursing care to the person who attempted suicide; the adult emergency service as a scenario of mental health practices; and permanent education-related needs in mental health Final considerations: initiatives capable to potentialize good practices in mental health care are still incipient and lack encouragement in the health service. There is an urgent need to think about changes in the care culture of the emergency service, especially to ensure the scope of psychosocial care actions.
\end{abstract}

Descriptors: Attempted Suicide; Nursing Care; Emergencies; Mental Health; Patient Reception.

\section{RESUMO}

Objetivo: analisar o cuidado de enfermagem às pessoas atendidas na emergência por tentativa de suicídio na percepção da equipe de enfermagem. Método: estudo exploratório e descritivo, de abordagem qualitativa, desenvolvido a partir de entrevista semiestruturada com oito enfermeiros e oito técnicos de enfermagem do serviço de emergência de um hospital universitário do Sul do Brasil. A análise dos dados ocorreu por meio de análise de conteúdo. Resultados: emergiram três categorias: cuidados de enfermagem à pessoa que tentou suicídio; o serviço de emergência adulto como cenário de práticas em saúde mental; e necessidades relacionadas à educação permanente em saúde mental. Considerações finais: iniciativas potencializadoras de boas práticas de cuidados em saúde mental ainda são tímidas e carecem de incentivo no serviço de saúde. Urge pensar em mudanças na cultura da assistência do serviço de emergência, sobretudo para garantir o alcance de ações de atenção psicossocial.

Descritores: Tentativa de Suicídio; Cuidados de Enfermagem; Emergências; Saúde Mental; Acolhimento.

\section{RESUMEN}

Objetivo: analizar el cuidado de enfermería a las personas atendidas en la emergencia por intento de suicidio en la percepción del equipo de enfermería. Método: estudio exploratorio y descriptivo, de abordaje cualitativo, desarrollado a partir de entrevista semiestructurada con ocho enfermeros y ocho técnicos de enfermería del servicio de emergencia de un hospital universitario del sur de Brasil. El análisis de los datos ocurrió por medio de análisis de contenido. Resultados: surgieron tres categorías: cuidados de enfermería a la persona que intentó suicidio; el servicio de emergencia adulto como escenario de prácticas en salud mental; y necesidades relacionadas con la educación permanente en salud mental. Consideraciones finales: las iniciativas impulsoras de buenas prácticas de atención de salud mental todavía son tímidas y carecen de incentivo en el servicio de salud. Es urgente pensar en cambios en la cultura de la asistencia del servicio de emergencia, sobre todo para garantizar el alcance de acciones de atención psicosocial.

Descriptores: Intento de Suicidio; Atención de Enfermería; Urgencias Médicas; Salud Mental; Acogimiento. 


\section{INTRODUCTION}

The suicidal ideation is formed in moments or behaviors, usually starting with threats of suicide, followed by an attempt and, finally, by the consummation of the self-extermination act. Suicide is more than the outcome of a personal behavior, becoming a sociocultural and psychosocial issue. Due to its multi-faceted characteristics, suicide is an event that must be face through interdisciplinary and intersectoral initiatives covering the areas of health, governmental and non-governmental actions ${ }^{(1)}$.

The number of deaths by suicide grows every year, reaching the mark of about 1 million cases. In Brazil, suicide is among the top ten causes of death, amounting to more than eleven thousand suicides in 2015, representing, on average, thirty-one death per day, being one of the leading three causes of death in the age group between 15 and 44 years old. For each one of these deaths, about five to six close people are affected and have some emotional, social, or economic consequence ${ }^{(2-4)}$.

In the world average, people attempt suicide twenty times more than actually consummate it. After the first attempt, the risk of a new try increases by up to one hundred times and, proportionately, also the number of attempts at a time interval ${ }^{(2)}$. With the high incidence and recurrence of suicide attempts, the health teams that provide service to urgencies and emergencies have a direct contact with this risk population, playing an important role since admission in the intervention and prevention of suicide, being able to establish interpersonal ties with the patients and, thus, allowing a better acceptance and adherence to treatment ${ }^{(5)}$.

The National Policy of Care and Urgency aims to ensure the universality, equality, and comprehensiveness in the emergency service. Therefore, the reception to the person who attempted suicide, as well as to their families, must be based on the comprehensiveness of care, attention, and solidarity actions, in addition to the respect to the full exercise of their citizenship ${ }^{(1,6)}$.

Nursing professionals in emergency services often are the first contact of the patient with the health system after a suicidal attempt or self-harm episode. The appropriate assessment and management of these patients is essential to prevent future suicidal behavior. However, these professionals often have a negative attitude in the face of these patients, lacking interpersonal skills to serve them and by inadequate assessment. Thus, understanding how the nursing team perceives the care provided to people in cases of suicidal attempt in an adult emergency room is necessary ${ }^{(7)}$.

The promotion of a care environment that is safe and conducive to their full recovery is essential in carrying out comprehensive care in mental health. The first step is the qualified listening, but it cannot be immersed in a bigoted discourse, full of judgement. One must consider that not always the person is willing to express or externalize what they really feel, and so a new challenge to the health professional emerges, which is the careful observation of the reality of the patient and the listening of silence, when the person is not willing to talk ${ }^{(8)}$.

The approach to this topic is a complex ask, but of utmost importance, considering the need to find ways to prevent such act and to provide to people who attempted suicide and their families and dignified and quality health care. Therefore, this study was guided by the following research question: how does occur the nursing care to people admitted in emergency for attempted suicide in the perception of the nursing staff?

\section{OBJECTIVE}

To analyze the nursing care to people admitted in emergency for attempted suicide in the perception of the nursing staff.

\section{METHOD}

\section{Ethical aspects}

This research follows the guidelines established by Resolution No. 466/2012 of the National Health Council(9), with approval of the Committee of Ethics in Research with Human Beings of the Federal University of Santa Catarina and opinion delivered on August 24, 2015. Prior to the data collection process, all participants signed the Informed Consent Form (IFC). Anonymity was ensured by the alphanumeric coding of the respondents, as the example: E1, E2 ... (nurses) and T1, T2 ... (nursing technicians).

\section{Type of study and methodological procedures}

Descriptive and exploratory study, of qualitative approach. Data collection occurred through a semi-structured interview with eight nurses and eight nursing technicians who work in the adult emergency service of a University Hospital (HU) in southern Brazil. The inclusion criterion was being part of the nursing team of the mentioned emergency unit, whereas the exclusion criterion was being away or absent from work during the period of data collection.

For the participants selection, the 'snowball' technique was used, in which the initial participants of a study indicate new participants who, for their time, indicate new participants and so on, until the proposed goal is reached. The saturation point is achieved when the new interviewees start to repeat the contents obtained in previous interviews, without adding new information that is relevant to the research. Therefore, the snowball is a technique that uses reference chains, i.e., a kind of network in which the research culminates with the interviews ${ }^{(10)}$.

\section{Data collection and organization}

The interviews were individually carried out in the physical space of the adult emergency in the $\mathrm{HU}$, in a multidisciplinary chamber, from prior scheduling with those involved, using a script as a guide. All responses were recorded in a voice recorder and transcribed in full for the data analysis, and then returned to the participants for content validation after transcription. Data collection occurred in the period from August 2015 to May 2016.

\section{Data analysis}

Data were evaluated through content analysis. The following steps were conducted in the interpretative phase: ordering of data, when he material was read and the reports were organized in the order in which they were obtained; and data classification, including: initial categorization, in which is was possible to seize the central ideas of the interviews, reordering of empirical data according to characteristics that are related with each other, and final analysis, in which the data were coupled to the theoretical 
foundation and the answer of the research question, based on the proposed objectives ${ }^{(11)}$.

\section{RESULTS}

When checking the profile of the nurses interviewed, we noticed that ages ranged between 23 and 36 years, six were female and two were male. The time working in the general emergency service ranged from two to nine years. Among them, four had completed or were working on a master's degree, and one had a Ph.D. Among the nursing technicians, in turn, four of them had completed the undergraduation, being three of them in nursing. Finally, all eight nurses had exclusive dedication to the $\mathrm{HU}$, unlike the eight nursing technicians, who had other employment relationships.

From the data analysis, three categories emerged, namely: nursing care to the person who attempted suicide; the adult emergency service as a scenario of mental health practices; and permanent education-related needs in mental health.

\section{Category 1: Nursing care to the person who attempted suicide} Regarding the clinical care, a nurse mentions that:

We perform the clinical part. The psychiatric nursing really is somewhat ignored and we end up not doing it. The care we try to perform here is giving support to the family, which often arrives here very unstructured, at least until the Psychology steps in. It is indeed a weakness, as we care more about the organic part of the patient. (E1)

Due to the little understanding on the subjective aspects involved in a suicide attempt, the negative reaction of the health team in the face of the suicidal person can be harmful to the provision of care, as the following statements:

I feel that we, as nurses, ave a deficit to care for this people. I don't feel much prepared, you know? And, as we have a professional [psychologist] that has specific training for this, it ends up that the nurse does not assume such care. So, for me, we practice a more technical, clinical care. (E5)

There is no preparation here, so I guess our care is not that good. We only perform the technical care, the rest is really done by the social service and psychology staff, the nursing team only makes the minimum. (E2)

Some respondents did not see the psychological focus as an inherent work of the nursing team, as they cite that this activity is being performed by other professionals of the sector (psychology and medicine) and that nursing addresses only technical issues of the care or the physical stabilization of the patients in acute state:

We practice comfort. We do not discuss why he [the patient] did it, we don't have this approach. This is more of a service to psychology and medicine, isn't it? Nursing does not deal much with this area because were are more involved in the actual care. (TE5)

In emergency, there is an intense dynamics. So there is no time specific for you to build a relationship or a connection with that specific patient. When this patient arrives, we mainly deal with the issue of intoxication, so they get all the treatment, and this part of investigation, the matter of humor, is not performed by the nurse here at the emergency due to our work demands and because we have a psychology professional. Thus, this psychological investigation on this person and what motivated this suicide attempt is at the discretion of the psychologist. (E4)

For other respondents, there is a guidance of the working process by the Nursing Care Systematization (history, diagnosis, planning, implementation, and evaluation), and the care provided is more related to measures of support, hemodynamic and neurological control, hygiene and comfort, vital signs, patient safety, surveillance, and request of other areas - such as the Toxicological Information Center (CIT) and the Psychology/ Psychiatry area -, as mentioned by two interviewees:

We usually check the vital signs, the level of consciousness, diuresis control, we end up exercising some vigilance... We keep the grid high so they don't fall. And the procedures arise as the Medicine requests them. (TE2)

The usually arrive unconscious, we put them on the stretcher, monitor them, check vital signs, as those who brought them whether some washing was done, what did they took, how much they took. We call the CIT, which comes to perform an evaluation, and usually they are the ones who describe what will be done depending on the drugs taken. Nursing care is pretty much it... Doing a well-made neurological evaluation, a proper physical examination, performing a hemodynamic control to see if the patient is not undergoing kidney injury. When there is a psychologist, we also already call them. We collect exams, medicate if necessary, puncture an access if the patient gets overexcited. And we continue evaluating the level of consciousness until they get better. (E2)

Other procedures reported by the respondents are: risk classification, high-caliber puncture, elevation of the bars, probe, diuresis control, collection of biological samples, cardiac monitoring, verification of vital signs (BP, CF, RF, SpO2, T), gastric lavage when necessary, the request of a full-time companion (surveillance) if possible, physical restraint when needed, medicine administration, hygiene care, and referrals for examinations.

\section{Category 2: The adult emergency service as a scenario of} mental health practices

The nursing team points out that the approach to the person who attempted suicide needs improvement to extrapolate the essentially technical care, but they also mentioned a weakness related to the environment which, according to them, is not adequate to receive a patient with such demand:

The environments is tumultuous sometimes, so we cease to give a better listening, a better reception, both for them as for their families, because of other demands we have. So, I think if we had a better structure, maybe this patient would not have how to escape, as it happens, and we could better monitor them, be more vigilant with certain issues... but here there is no how. (E6)

In an emergency we see those things about keeping the environment peaceful, safe, an adequate space. But we know that in emergency this is not so viable, we do not have a physical space compatible to these guidelines. (TE2) 
Work overload is reported as an obstacle in the provision of mental health care, as in the following report:

Firstly, we cannot do a proper approach because we are not mentally and emotionally prepared for that. We try [to provide a proper mental health care], but is all very fast, always in a hurry, we are already overloaded with other technical stuff and can't focus on that part... Because there is one nurse for thirty patients, sometimes you have thirty patients there and you have to know what hey are and what they are doing. There are days we can't even make a decent medical history. (E2)

They also point out deficits related to comprehensive care, justified by the routine in emergency services. In the following statements, the participants mentioned some of the difficulties of nursing professionals when providing nursing care to people in psychic distress:

Here in the ER we cannot do a follow up, I think that the integral care is not done. We have a more fragmented care because it is more immediate, we do what we have to do at that moment. After, the psychology staff usually assumes this issue of checking mental health care and monitoring this patient. (E5)

The nurse can even talk to them a little, but that's a lot of people here, too much flow. So I believe that the care is not complete, full, it always ends up leaving that part to the psychologist or social worker. I always try to, when I do my visits, talk a little with this patient, but it is complicated due to the demand and with everyone calling you. (E3)

Sometimes, being unable to perform the nursing care as they would like to and to develop the work promoting care comprehensiveness can also be a cause for suffering to the own health professions, who understand their limitations and have no control over them, as in the following statements:

We have her a very large demand and very few employees. If we had more staff, maybe the attendance to this kind of patient would be better. It is all so hectic, sometimes we cannot stop to listen to the person. (TE3)

I perform my care based on scientific knowledge but, sometimes, even knowing that something is more adequate I don't do it - not because I do not know what to do, but because the work dynamics doesn't allow me to do it, the work process precludes me from doing it. (E7)

We should have a better environments for this patient. Sometimes it is a patient with suicidal ideation, that still has such ideation, and he sits on a stretcher in the middle of the hallway, in front of everyone. Or sometimes it is a patient who needs to be more recluse, and they stay in the corridor. I think that this environmental issue much influences the patient. (E8)

The studied service does not have Psychology and Psychiatry professionals all days of the week, nor on all shifts. In the following reports, the participants mentioned the importance of the nursing team addressing the mental health care in the absence of other professional, but identified the multi-professional team (psychologist/social worker) as essential for this care to occur. Also noteworthy is the perception of the functions as parted from each other, established between the different professionals.

Sure, if we could address [the mental health care] would be great, as we not always have a psychologist. In weekends there is none, and it happens a lot, then we refer them to the social services, which also can have another view. I'm here for it and I'm going to do the best I can. But anytime I can delegate this activity to the psychologist, I do it. So we try to run away a little from what is not our profile, you see? (E2)

We do our approach, not the approach to the patient. Medicine performs its approach and then passes on to Psychology. We end up doing only nursing care and knowing more or less what happened. (TE5)

\section{Category 3: permanent education-related needs in mental health}

Interviewees also pointed out the need for better preparation for mental health care, whether in the educational institution or through training on the job. In their interviews, they emphasize the importance of trainings to address issues related to the care for people in the mental health field, as shown in the statements:

There should be more training. Maybe a joint work with the Psychology. Bring to the staff which are the types of intoxication, the kind of urgency we have here. And not only the clinical part of what happens to the patient, but also the attendance, the psychological part, the "after", or even the administrative part. Several faces of an attendance! Bring the team to for a team de facto! More trained, more cohesive. I believe that maybe this training would help. (TE1)

It is well away from what it should be due to the lack of preparation of the professionals. This issue of mental health needs to be better worked at the undergraduation. I did graduate and we had no internships about it, not even in CAPS [Psychosocial Care Center] nor in [psychiatric hospital]. We had only internships in basic health units, where the demand is very different and we don't get to see a patient in crisis. (TE4)

There's a real demand here, even a significant one. Professionals need to be trained to perform such care. And that's something we don't see, I'm been here for 6 years and I've never seen any training available on this mental health issue, focused on emergency care. This is something we really don't have. (TE4)

After pointing the weaknesses of the care developed in the unit, some interviewees idealized situations that should occur, wishes they would like to see realized, and daily confrontations for changing this situation:

The health system today works in a logic that simply doesn't work, which is fragmented, where the care units of the network do not communicate. So nobody assumes this person [who attempted suicide], they are loose in this system because the ideal would be that this patient left having a reference, not just a piece of paper saying "now you go to CAPS" or "now you go to the primary health care." (E5) 
However, some of the professionals interviewed believe that the emergency room of a general hospital is not the appropriate plate to receive and treat the mental health patient and that, whenever possible and depending on the severity, they should be transferred to the psychiatric hospital of to other specialized care in the area, refuting the assumption of the Psychiatric Reform, as presented in the reports that follow:

Outbreak patients are referred to the [psychiatric hospital]. It has to be, there's no other way. There they are admitted, staying for three, four days as inmates, no visitors, no nothing. That's the way it's supposed to be. So there's much information missing in the family, because the family shouldn't even bring them here, which is a general hospital. I don't know, they think the HU is all, the HU has all, but the HU does not have everything! They should know: 'look, you go to the [psychiatric hospital], there the doors are always open, there is emergency care too'. People don't know that, they are misinformed. (E2)

There was that reform [Psychiatric Reform] some few years ago, and several asylums were closed. I don't know to what extent this was interesting. It was nice because people are no longer confined, but there is no reference on where they go to, this reference is lost. Here, we only have the [psychiatric hospital]. I believe that the ideal would be having a single location for these patients to go, a place that cares for psychiatric patients 24/7, with a prepared team. The CAPS has a team, a team to support, to care for the family, that is trained for it. (E2)

The major flaw in the service, in the system, mostly here within emergency, is the admittance: the [psychiatric] patient, with such condition, is in the same condition o a patient who, I don't know, broke an arm, and these are completely different things. (E4)

This is a patient who, if there was a psychiatric emergency, we could care for them better. Given the other demands we have, we not always can give this psychological contribution in an ideal way, take time to stope, talk, host. Such patients demand great care, mostly surveillance and family orientation. (E6)

\section{DISCUSSION}

The nursing care provided to people served in emergency due to attempted suicide has been presented with a more biological approach, which decouples the physical part of the psychological one. Nursing team professionals understand that this dissociations is a limitation in the care, but that some circumstances of in the course the work journey do not allow the execution of a humanized and comprehensive care.

The daily confrontations mentioned both justify this practice of biological care as difficult its overcoming: the work overload, the unit dynamics and turnover, the lack of preparation as a result of inadequate training in mental health, the lack of institutional support both for trainings and permanent education, the hegemonic biomedical model in the institution, the nature of the emergency service, with limited physical structured and focused on providing a care aimed at patient (biological) stabilization.
However, the respondents also mentioned they seek to achieve the best care possible based on the Urgency Care Policy, aimed at the reception with risk classification and case management, uniting and integrating health equipment and expanding and qualifying the humanized and comprehensive access to patients in urgency/emergency situations in the health services $^{(6)}$.

For the care to surpass the technical focus, the psychological care and the continuous observation of patients and family members are also necessary, aiming to prioritize the communication in accordance with the qualified listening, as these patients are often insecure. It is important to highlight that all people who attempted suicide should receive professional care due to the emotional fragility in which they find themselves. The competence of the emergency team is saving lives, considering not only the physical aspects but also the psychological aspects involved in the process of caring ${ }^{(12-13)}$.

However, as noted in the results, the daily practice of the care provided to people who attempt suicide in emergency units is, for the most part, tumultuous and demand great attention of the whole health team. Professionals there direct their primary attention to vital life support care, stalling the psychological to that patient, as well as to the family of the individual who attempted suicide $^{(14)}$.

Such idea of care fragmentation in emergency services at the expense of a comprehensive health care needs to be abandoned. The World Health Organization (WHO) defines health as a state of complete physical, mental, and social well-being, not just the absence of diseases ${ }^{(15)}$. Thus, the concept of health seeks to understand the human being as a biopsychosocial being, i.e., a biological, social, and psychological being, which should be attended considering these aspects.

Mental health care involves personal, social, emotional, and financial issues, related to mental illness. Such care involves a demand for attention that is not always put into effect due to numerous difficulties experience both by the patients as by the professionals and the society. Among them, we point the scarcity of resources, the inadequacy of the professional care, the stigma, the violations of patients' rights, among others ${ }^{(16)}$.

The humanized care to the patient is that in which there is permeability between technical and non-technical aspects. To enable a practical wisdom, being open to and interested in listening and meeting the other. Most of the time, the first difficulty encountered in the emergency room of a hospital is the insensitivity of the health team regarding the emotional aspects of the patient who attempted suicide ${ }^{(1)}$.

Thus, there are some essential behaviors that nursing can use to meet a person who attempted suicide or has a suicidal ideation, namely: listen carefully, be empathetic, convey nonverbal messages of acceptance, express respect for the opinion of another, talk honestly, show concern, and focus on the feelings of the person. The mere interaction with the patient has a great potential to calm down, prevent, or minimize the severity and intensity of the symptoms. Still, the team should try to establish a bond of trust from the start, whereas, on the other hand, the idea that the patient attempted suicide to manipulate others should be abandoned ${ }^{(17-18)}$. 
The reality of hospital emergency, sometimes hectic, can be an obstacle to the humanization of the care to people in psychic suffering. In its academic training, the health tea learns how to take care of the organic body, with less emphasis on emotional and behavioral issues of mental health, which is reflected in their actions in the field of work, in which the team takes care of the physical body of the patient and often does not observe the emotional aspects ${ }^{(3)}$.

Weaknesses in the theoretical and operation design, in addition to the professionals' personal conflicts concerning suicide, trigger a plot o no-personal involvement with this patient over the process of care. Theoretically, nursing professionals realize the impossibility of dividing the body into biological and psychological dimensions. However, he focus of their work is essentially biological, with initial focus on the physical stabilization of the patient, delegating the mental health care to other professions. While not denying the mental health care, in practice it has not been developed by the nursing staff.

This reality shows the relevance of continuous training of the nursing team to care for patients who attempt suicide. Numerous studies indicate that nurses and other health professionals receive little or no education regarding suicide. So that there is a qualified care, it is essential that nursing professionals have preparation and technical skills to meet the emergencies of people who attempted suicide, conducting an empathetic approach, with competence in dealing with this kind of occurrence. Nonetheless, these patients are subjected to stigmatization and lack of empathy, leading to a decreased quality of care. An intense permanent education policy of institutional scope is fundamental for the entire health team ${ }^{(1,13)}$.

Finally, other studies agree with the results found here, that, in the context of mental health, health teams usually distinguish between physical and mental problems, which leads to the fragmentations of care to the person and devaluation of patients with mental health problems, thus revealing a culture influences by an asylum imaginary ${ }^{(7)}$. The psychiatric reform comes to break with some paradigms posed by society, among which this distinction in the team's approach regarding physical and mental body, as well as the power structures and the dignity involving the care practices in such spaces.

\section{Study limitations}

The limitations of this study are related to the number of professionals involved in it, as well as the specificity of the emergency services studied, and may not represent the wider reality regarding the care provided in a suicide attempt.

\section{Contributions to the fields of health and nursing}

The need for addressing this issue is significant since the suicide mortality rate has increased considerably in recent years, becoming a public health problem. Understanding the factors correlated to the reasons why the person tried to commit suicide and the care practices scientifically developed and, mainly, humanized becomes essential both for the benefit of the patients as to preserve the health of those who care for them.

We expect this study brings contributions related to the way Nursing has been acting in the mental health care in hospital emergency contexts, on its own standpoint, especially concerning the health care in attempted suicides - thus leading to a change in praxis.

\section{FINAL CONSIDERATIONS}

In the perception of nursing professionals, the description of the care provided to the person who attempted suicide presented an essentially technical tendency. They manifest in their speeches that they feel affected by the constant obstacles in the care provision, such as work overload, lack of support from the institution, and lack of preparation, reflection of a poor initial and ongoing training in mental health. Yet, they report that they seek to provide the best care possible, even with difficulties.

Initiatives capable to potentialize good practices in mental health care are still incipient and lack encouragement in the health service. In the field of nursing, in particular, require a cultural and technical change for the development of psychosocial attention actions inf all health care contexts.

Despite the importance of the results obtained in this study, further research in this area of health care would be relevant, since it impacts the behavior of professionals in hospital emergency services, as well as other areas of mental health care.

\section{REFERENCES}

1. Wallauer A, Maliska ME. Suicídio: um desafio para os profissionais da saúde. Florianópolis: Editora Pandion; 2012.

2. Botega NJ. Suicidal behavior: epidemiology. Psicol Usp[Internet]. 2014[cited 2016 May 05];25(3):231-6. Available from: http:// www.scielo.br/pdf/pusp/v25n3/0103-6564-pusp-25-03-0231.pdf

3. Gutierrez BAO. Assistência hospitalar na tentativa de suicídio. Psicol USP[Internet]. 2014[cited 2016 May 05];25(3):262-9. Available from: http://www.scielo.br/pdf/pusp/v25n3/0103-6564-pusp-25-03-0262.pdf

4. Brasil. Ministério da Saúde. Datasus. Sistema de Informação sobre Mortalidade-SIM[Internet]. 2015[cited 2016 May 05]. Available from: http://tabnet.datasus.gov.br

5. Vidal CAL, Gontijo ECDM, Lima LA. Attempted suicide: prognostic factors and estimated excess mortality. Cad Saúde Pública[Internet]. 2013[cited 2016 May 12];29(1):175-87. Available from: http://www.scielo.br/pdf/csp/v29n1/20.pdf

6. Brasil. Ministério da Saúde. Secretaria de Atenção à Saúde. Política Nacional de Atenção às Urgências[Internet]. Brasília: MS; 2006[cited 2016 May 12]. Available from: http://bvsms.saude.gov.br/bvs/publicacoes/politica_nacional_atencao_urgencias_3ed.pdf

7. Carmona-Navarro MC, Pichardo-Martinez, MC. Attitudes of nursing professionals towards suicidal behavior: influence of emotional intelligence. Rev Latino-Am Enferm[Internet]. 2012[cited 2016 May 12];20(6):1161-8. Available from: http://www.scielo.br/pdf/ 
rlae/v20n6/19.pdf

8. Pitta AMF, Coutinho DM, Rocha CCM. Direitos humanos nos Centros de Atenção Psicossocial do Nordeste do Brasil: um estudo avaliativo, tendo como referência o QualityRights-WHO. Saúde Debate[Internet]. 2015[cited 2016 Apr 12];39(106):760-71. Available from: http://www.scielo.br/pdf/sdeb/v39n106/0103-1104-sdeb-39-106-00760.pdf

9. Brasil. Plenário do Conselho Nacional de Saúde. Resolução n 466, de 11 de janeiro de 2012 que dispõem da aprovação de diretrizes e normas regulamentadoras de pesquisas envolvendo seres humanos[Internet]. 2012[cited 2016 Apr 12]. Available from: http://bvsms.saude.gov.br/bvs/saudelegis/cns/2013/res0466_12_12_2012.html

10. Baldin N, Munhoz EMB. Snowball (Bola de neve): uma técnica metodológica para pesquisa em educação ambiental comunitária. Educere[Internet]. 2011[cited 2016 May 17];329-41. Available from: http://educere.bruc.com.br/CD2011/pdf/4398_2342.pdf

11. Minayo MCS, (Org.). Pesquisa social: teoria, método e criatividade. 29. ed. Petrópolis, RJ: Vozes, 2010.

12. Sá ACA, Medeiros MFN, Diniz ERS, Silva MLN, Medeiros SS. Percepções dos profissionais de enfermagem acerca do cuidar do paciente suicida. FIEP Bull[Internet]. 2012[cited 2016 Apr 12];82(2). Available from: http://www.fiepbulletin.net/index.php/ fiepbulletin/article/view/2408/4503

13. Bird T. Suicide prevention in the non-psychiatric hospital setting: a nurse education process[Tese]. Boise City (Idaho): Boise State University; 2017[cited 2017 Jul 04]. 78p. Available from: http://scholarworks.boisestate.edu/cgi/viewcontent.cgi article $=1012 \&$ context $=$ dnp

14. Buriola AA, Arnauts I, Decesaro MN, Oliveira MLF, Marcon SS. Nursing assistance to a family of a member who attempted suicide. Esc Anna Nery Rev Enferm[Internet]. 2011[cited 2016 May 12];15(4):710-6. Available from: http://www.scielo.br/pdf/ean/v15n4/ a08v15n4.pdf

15. World Health Organization-WHO. Constitution of the World Health Organization. Basic Documents. 1946. Genebra: WHO.

16. Cardoso L, Galera SAF. Mental health care today. Rev Esc Enferm USP[Internet]. 2011[cited 2016 Apr 12];45(3):687-91. Available from: http://www.scielo.br/pdf/reeusp/v45n3/en_v45n3a20.pdf

17. Brasil. Ministério da Saúde. Secretaria de Atenção à Saúde. Prevenção do Suicídio: manual dirigido a profissionais das equipes de saúde mental[Internet]. 2006[cited 2016 Apr 12]. Available from: http://bvsms.saude.gov.br/bvs/publicacoes/manual_editoracao.pdf

18. Haris B, Beurmann R, Fagien S, Shatell MM. Patients' experiences of psychiatric care in emergency departments: a secondary analysis. Int Emerg Nurs[Internet]. 2016[cited 2017 Jul 04];26:14-9. Available from: http://www.sciencedirect.com/science/article/ pii/S1755599X15000932 